\title{
Neoclerodanes from Teucrium orientale
}

\author{
Maurizio Bruno, ${ }^{a}$ Sergio Rosselli, ${ }^{a}$ Antonella Maggio, ${ }^{a}$ Franco Piozzi,,${ }^{a}$ Leonardo Scaglioni, ${ }^{b}$ \\ Nelly A. ARnold, ${ }^{c}$ and Monique S. J. SimMONDs ${ }^{*}, d$ \\ a Dipartimento di Chimica Organica “E. Paternò”, Università di Palermo, Viale delle Scienze; Parco d'Orleans II, 90128 \\ Palermo, Italy: ${ }^{b}$ Dipartimento di Scienze Molecolari Agroalimentari, Università di Milano; Via Celoria 2, 20133 Milano, \\ Italy: ${ }^{c}$ Universitè du Saint Esprit, Facultè de Agronomie; Kaslik, Beirut, Lebanon: ${ }^{d}$ Jodrell Laboratory, Royal Botanic \\ Gardens; Kew, Richmond, Surrey TW9 3AB, U.K. Received July 26, 2004; accepted September 13, 2004
}

Two new neoclerodane diterpenoids, 6-deacetyl-teucrolivin A (5) and $8 \beta$-hydroxy-teucrolivin B (6), were isolated from the aerial parts of Teucrium orientale, along with four already known neoclerodane diterpenoids, teucrolivin A (1), teucrolivin B (2), teucrolivin C (3) and teucrolivin H (4), previously isolated from Teucrium oliverianum. Their structures were elucidated on the basis of spectroscopic evidence and chemical transformations. Compounds 1-3 were assayed for antifeedant activity against Spodoptera littoralis, $S$. frugiperda and Heliocoverpa armigera. Teucrolivin A was the most potent of the three compounds tested.

Key words Lamiaceae; Teucrium orientale; structure elucidation; neo-clerodane diterpenoid; antifeedant activity

The chemistry of the genus Teucrium (Lamiaceae) has been investigated by our group for the last forty years. It contains more than 300 species, ${ }^{1)}$ many of them occurring in the Mediterranean region. ${ }^{2)}$ To date, the only diterpenoids isolated from the aerial parts of Teucrium are those with a neoclerodane skeleton. More than 220 diterpenes have been described, all differing in the functional groups on the neoclerodane or 19-nor-neoclerodane skeleton. ${ }^{3-6)}$ These secondary metabolites are of interest because of their ecological role as antifeedant against some species of insects, ${ }^{7-9)}$ and potential role in the medicinal properties of the plants. ${ }^{10-18)}$

As part of our investigations of this genus, we report here the results of the phytochemical analysis of Teucrium orientale L., a species occurring in the Lebanon-Syria-Israel-Jordan area. The sample of Teucrium orientale now investigated comes from Lebanon, where is named "oja'dah sharqiyah". It is botanically similar to Teucrium oliverianum (GING. ex BENTH.) R.Br., a species occurring in the area from Jordan to Saudi Arabia from which many compounds were isolated. ${ }^{19-24)}$

Many species of Teucrium are known for their utilization in traditional folk medicine and are claimed to exhibit interesting biological properties such as hypoglycaemic, hypolipidemic, antioxidant, antipyretic, anti-inflammatory, antiulcer, antitumor and antibacterial. ${ }^{10-18)}$ Some species are used as a tonic or to treat various ailments like stomach and intestinal problems, colds and for feminine sterility. ${ }^{25}$

In Lebanon, an infusion of the flowers of Teucrium orientale is used in folk medicine as as hypoglycaemic, vermifuge, antipyretic and to treat stomach and intestinal problems.

Column chromatography was used to isolate six neoclerodane diterpenoids: four of them are already known, having been isolated from Teucrium oliverianum: teucrolivin A (1), teucrolivin B (2), teucrolivin C (3), ${ }^{19)}$ teucrolivin $\mathrm{H}(\mathbf{4}){ }^{21)}$ Two neoclerodanes are new products: they were ascribed the structures of 6-deacetyl-teucrolivin A (5) and of $8 \beta$-hydroxyteucrolivin B (6), on the basis of spectroscopic evidence and chemical transformations.

Compound $5\left(\mathrm{C}_{22} \mathrm{H}_{28} \mathrm{O}_{8}\right)$ had an IR spectrum which was

consistent with the presence of hydroxyl groups (3490, $\left.3450 \mathrm{~cm}^{-1}\right)$, a furan ring $\left(1505,874 \mathrm{~cm}^{-1}\right)$, a ketone $\left(1725 \mathrm{~cm}^{-1}\right)$, an oxirane $\left(3040 \mathrm{~cm}^{-1}\right)$ and an acetate $(1745$, $\left.1229 \mathrm{~cm}^{-1}\right)$. The ${ }^{1} \mathrm{H}$ - and ${ }^{13} \mathrm{C}$-NMR spectra of compound 5 (Tables 1,3) suggested a structure closely related to teucrolivin A (1) ${ }^{19)}$ the main difference being the upfield shift of the signal of $\mathrm{H}-6 \beta$ proton $\left[\delta_{\mathrm{H}} 4.09(1 \mathrm{H}, \mathrm{dd}, J=12.0,3.8 \mathrm{~Hz})\right]$ of compound 5 with respect to that of teucrolivin A. Therefore we assigned compound 5 the structure, 6-deacetyl-teucrolivin A. In agreement with the above conclusions, acetic anhydride-pyridine treatment of compound 5 gave teucrolivin A (1), allowing us also to assign to compound $\mathbf{5}$ the absolute configuration of neoclerodane since the absolute configuration of teucrolivin $\mathrm{A}$ is well known. ${ }^{19)}$

The ${ }^{1} \mathrm{H}$ - and ${ }^{13} \mathrm{C}$-NMR spectra (Tables 2,3 ) of the second new diterpenoid (6) $\left(\mathrm{C}_{24} \mathrm{H}_{32} \mathrm{O}_{10}\right)$ revealed the presence of a $\beta$-substituted furan, an acetoxymethylene group at the $\mathrm{C}-19$ position and a $4 \alpha-18$ oxirane ring identical with those found in compound 5. There were also signals for an equatorial

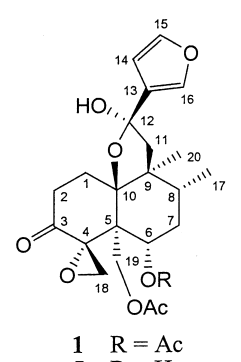

$\begin{array}{ll}1 & \mathrm{R}=\mathrm{Ac} \\ \mathbf{5} & \mathrm{R}=\mathrm{H}\end{array}$

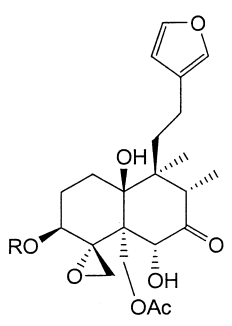

$2 \mathrm{R}=\mathrm{Ac}$ $\begin{array}{ll}2 & \mathrm{R}=\mathrm{A} \\ 3 & \mathrm{R}=\mathrm{H}\end{array}$

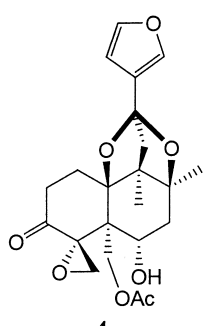

4

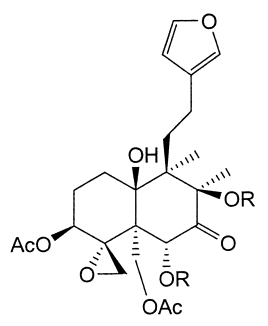

$6 \quad \mathrm{R}=\mathrm{H}$

* To whom correspondence should be addressed. e-mail: m.simmonds@rbgkew.org.uk 
secondary acetoxyl group at the $\mathrm{C}-3 \beta$ position $\left[\delta_{\mathrm{H}} 5.20(1 \mathrm{H}\right.$, $\mathrm{dd}, J=11.0,5.3 \mathrm{~Hz}, \mathrm{H}-3 \alpha)]$, a $\mathrm{C}-7$ ketone function $\left[\delta_{\mathrm{C}}\right.$ $208.56(\mathrm{C}-7)]$, a secondary C-6 hydroxyl group $\left[\delta_{\mathrm{H}} 5.39\right.$ $(1 \mathrm{H}$, br s, H-6 $\beta)$ ], a tertiary (C-20) methyl group, a tertiary $(\mathrm{C}-17)$ methyl group geminated to a hydroxyl group $\left[\delta_{\mathrm{H}} 1.34\right.$ $\left(3 \mathrm{H}, \mathrm{s}, \mathrm{Me}-17 ; \delta_{\mathrm{C}} 17.04(\mathrm{C}-17)\right],\left[\delta_{\mathrm{C}} 84.33(\mathrm{C}-8)\right]$, a C-10 tertiary hydroxyl group $\left[\delta_{\mathrm{C}} 82.27(\mathrm{C}-10)\right]$ and three hydroxyl groups $\left[\delta_{\mathrm{H}} 5.59(1 \mathrm{H}, \mathrm{s}) ; 4.75(1 \mathrm{H}, \mathrm{s}) ; 3.73(1 \mathrm{H}, \mathrm{s})\right]$ that disappeared after addition of $\mathrm{D}_{2} \mathrm{O}$. In order to assign the relative configuration to all the stereogenic centers a ROESY ${ }^{26}$ (Rotating frame Overhauser effect spectroscopy) experiment was carried out (Table 2). The correlation between H-18a and H-6 confirmed the $\beta$-orientation of the latter. Furthermore, the correlation between Me-20 and $\mathrm{H}-1 \alpha$ showed that they must be close, in a cis 1,3-diaxial relationship, and, consquently the hydroxy group at $\mathrm{C}-10$ has to be $\beta$-orien-

Table 1. ${ }^{1} \mathrm{H}-\mathrm{NMR}$ Spectral Data of Compound $5\left(600 \mathrm{MHz}, \mathrm{CDCl}_{3}\right)$

\begin{tabular}{cl}
\hline \hline $\mathrm{H}$ & \multicolumn{1}{c}{$\mathrm{ppm}$} \\
\hline $1 \alpha$ & $2.21 \mathrm{ddd}(J=14.0,12.0,5.8 \mathrm{~Hz})$ \\
$1 \beta$ & $2.49 \mathrm{ddd}(J=14.0,8.0,1.7 \mathrm{~Hz})$ \\
$2 \alpha$ & $2.64 \mathrm{ddd}(J=17.2,5.8,1.7 \mathrm{~Hz})$ \\
$2 \beta$ & $2.84 \mathrm{ddd}(J=17.2,12.0,8.0 \mathrm{~Hz})$ \\
$6 \beta$ & $4.09 \mathrm{dd}(J=12.0,3.8 \mathrm{~Hz})$ \\
$7 \alpha$ & $1.25 \mathrm{ddd}(J=13.4,12.0,11.4 \mathrm{~Hz})$ \\
$7 \beta$ & $1.48 \mathrm{ddd}(J=13.4,3.8,3.8 \mathrm{~Hz})$ \\
$8 \beta$ & $1.75 \mathrm{ddq}(J=11.4,3.8,7.0 \mathrm{~Hz})$ \\
$11 \alpha$ & $2.33 \mathrm{~d}(J=13.8 \mathrm{~Hz})$ \\
$11 \beta$ & $2.45 \mathrm{~d}(J=13.8 \mathrm{~Hz})$ \\
14 & $6.38 \mathrm{dd}(J=1.5,1.2 \mathrm{~Hz})$ \\
15 & $7.48 \mathrm{br} \mathrm{s}$ \\
16 & $7.48 \mathrm{br} \mathrm{s}$ \\
$\mathrm{Me} 17$ & $0.80 \mathrm{~d}(J=7.0 \mathrm{~Hz})$ \\
$18 \mathrm{a}$ & $3.42 \mathrm{~d}(J=5.0 \mathrm{~Hz})$ \\
$18 \mathrm{~b}$ & $2.91 \mathrm{~d}(J=5.0 \mathrm{~Hz})$ \\
$19 \mathrm{a}$ & $4.85 \mathrm{~d}(J=12.0 \mathrm{~Hz})$ \\
$19 \mathrm{~b}$ & $4.31 \mathrm{~d}(J=12.0 \mathrm{~Hz})$ \\
$\mathrm{Me} 20$ & $1.07 \mathrm{~s}$ \\
OAc & $2.00 \mathrm{~s}$ \\
\hline
\end{tabular}

tated. Finally, the correlation between Me-20 and Me-17 and the absence of correlation between Me-17 and H- $6 \beta$ clearly indicated a $\beta$-orientation of the hydroxy group at $\mathrm{C}-8$. These facts allowed us to assign a structure of $8 \beta$-hydroxy-teucrolivin B to compound $\mathbf{6}$.

Acetic anhydride-pyridine treatment of $\mathbf{6}$ at room temperature for $1 \mathrm{~d}$, yielded compound $7\left(\mathrm{C}_{28} \mathrm{H}_{34} \mathrm{O}_{12}\right)$ that showed the presence of four acetoxyl groups $\left[\delta_{\mathrm{H}} 2.21(3 \mathrm{H}, \mathrm{s}), 2.14(3 \mathrm{H}\right.$, s), $2.10(3 \mathrm{H}, \mathrm{s}), 2.02(3 \mathrm{H}, \mathrm{s})]$ and of a hydroxyl group $\left[v_{\mathrm{OH}}\right.$ $\left.3562 \mathrm{~cm}^{-1}\right],\left[\delta_{\mathrm{H}} 4.24(1 \mathrm{H}, \mathrm{s})\right]$ that disappeared after addition of $\mathrm{D}_{2} \mathrm{O}$. The downfield shift of $\mathrm{H}-6 \beta\left[\delta_{\mathrm{H}} 6.03(1 \mathrm{H}, \mathrm{brs})\right]$ clearly showed that the $\alpha$-hydroxyl group at C- 6 of compound 6 was acetylated. In order to determinate the position of the fourth acetoxyl group a HMBC (heteronuclear multiple-bond correlation) ${ }^{27)}$ experiment was carried out (Table 2). The tertiary methyl group at $\delta_{\mathrm{H}} 1.57(\mathrm{Me}-17)$ showed correlations with the quaternary carbons at $\delta_{\mathrm{C}} 92.12(\mathrm{C}-8)$, $\delta_{\mathrm{C}} 199.25(\mathrm{C}-7)$ and $\delta_{\mathrm{C}} 50.94(\mathrm{C}-9)$ and on the other hand the tertiary methyl group at $\delta_{\mathrm{H}} 0.89(\mathrm{Me}-20)$ correlated with the three quaternary carbons at $\delta_{\mathrm{C}} 92.12(\mathrm{C}-8), \delta_{\mathrm{C}} 50.94$ $(\mathrm{C}-9)$ and $\delta_{\mathrm{C}} 82.59(\mathrm{C}-10)$. Furthermore the hydroxyl group $\left[\delta_{\mathrm{H}} 4.24\right]$ showed clear correlations with the two quaternary carbons at $\delta_{\mathrm{C}} 50.94(\mathrm{C}-9)$ and $\delta_{\mathrm{C}} 82.59(\mathrm{C}-10)$, and with the methylenic carbon at $\delta_{\mathrm{C}} 28.23(\mathrm{C}-1)$. From all the above data it was evident that compound 7 possessed an acetoxyl group at $\mathrm{C}-8$ and a free hydroxyl group at $\mathrm{C}-10$.

The absolute configuration of $8 \beta$-hydroxy-teucrolivin $\mathrm{B}$ (6) was not ascertained but is believed to belong to the neoclerodane series like teucrolivins A (1), B (2) and C (3), co-occurring in the same species.

The known compounds were identified by direct comparison (TLC, ${ }^{1} \mathrm{H}$ - and ${ }^{13} \mathrm{C}-\mathrm{NMR}$, IR and $[\alpha]_{\mathrm{D}}$ ) with compounds previously isolated from Teucium oliverianum in our laboratory. Copies of the original spectra are obtainable from the corresponding author. ${ }^{13} \mathrm{C}$-NMR data of teucrolivin $\mathrm{H} \mathrm{(4)}$ are included in Table 3 as they were not previously reported. ${ }^{21}$

A binary choice feeding bioassay using either glass-fibre discs (Spodoptera littoralis, S. frugiperda and Heliocoverpa

Table 2. ${ }^{1} \mathrm{H}-\mathrm{NMR}$ Spectral Data of Compounds 6 and $7\left(600 \mathrm{MHz}, \mathrm{CDCl}_{3}\right)$

\begin{tabular}{|c|c|c|c|c|}
\hline $\mathrm{H}(\mathrm{ppm})$ & 6 & ROESY & 7 & HMBC \\
\hline $1 \alpha$ & 2.02 o.s. & $\mathrm{H}-3 \alpha, \mathrm{H}-19 \mathrm{a}, \mathrm{Me}-20$ & o.s. & \\
\hline $3 \alpha$ & $5.20 \mathrm{dd}(J=11.0,5.3 \mathrm{~Hz})$ & H-19a, H-1 $\alpha$ & $5.25 \mathrm{dd}(J=10.5,5.4 \mathrm{~Hz})$ & $\mathrm{C}-18, \mathrm{C}-4,169.68(\mathrm{C}=\mathrm{O})$ \\
\hline $6 \beta$ & $5.39 \mathrm{brs}$ & $\mathrm{H}-18 \mathrm{a}$ & $6.03 \mathrm{brs}$ & $\mathrm{C}-5, \mathrm{C}-19,169.33(\mathrm{C}=\mathrm{O}), \mathrm{C}-7$ \\
\hline $12 \mathrm{a}$ & $2.58 \mathrm{~m}$ & & $2.62 \mathrm{~m}$ & $\mathrm{C}-11, \mathrm{C}-14, \mathrm{C}-13, \mathrm{C}-16$ \\
\hline $12 \mathrm{~b}$ & $2.55 \mathrm{~m}$ & $\mathrm{Me}-20$ & $2.57 \mathrm{~m}$ & $\mathrm{C}-11, \mathrm{C}-14, \mathrm{C}-13, \mathrm{C}-16$ \\
\hline 14 & $6.30 \mathrm{brd}(J=1.4 \mathrm{~Hz})$ & & $6.32 \mathrm{brd}(J=1.6 \mathrm{~Hz})$ & $\mathrm{C}-13, \mathrm{C}-16, \mathrm{C}-15$ \\
\hline 15 & $7.37 \mathrm{brd}(J=1.4 \mathrm{~Hz})$ & & $7.41 \mathrm{brd}(J=1.6 \mathrm{~Hz})$ & $\mathrm{C}-14, \mathrm{C}-13, \mathrm{C}-16$ \\
\hline 16 & $7.27 \mathrm{brs}$ & & $7.29 \mathrm{brs}$ & $\mathrm{C}-14, \mathrm{C}-13, \mathrm{C}-15$ \\
\hline Me-17 & $1.34 \mathrm{~s}$ & $\mathrm{Me}-20$ & $1.57 \mathrm{~s}$ & $\mathrm{C}-9, \mathrm{C}-8, \mathrm{C}-7$ \\
\hline $18 \mathrm{a}$ & $3.17 \mathrm{~d}^{a)}(J=3.0 \mathrm{~Hz})$ & $\mathrm{H}-6 \beta$ & $2.91 \mathrm{~d}(J=3.8 \mathrm{~Hz})$ & $\mathrm{C}-4$ \\
\hline $18 \mathrm{~b}$ & $3.10 \mathrm{~d}^{b)}(J=3.0 \mathrm{~Hz})$ & & $2.89 \mathrm{~d}(J=3.8 \mathrm{~Hz})$ & C-4 \\
\hline $19 \mathrm{a}$ & $4.45 \mathrm{~d}(J=12.2 .0 \mathrm{~Hz})$ & Me-20, H-1 $\alpha, \mathrm{H}-19, \mathrm{H}-3 \alpha$ & $4.42 \mathrm{~d}(J=12.2 \mathrm{~Hz})$ & $\mathrm{C}-5, \mathrm{C}-4, \mathrm{C}-6, \mathrm{C}-10,170.63(\mathrm{C}=\mathrm{O})$ \\
\hline $19 \mathrm{~b}$ & $3.97 \mathrm{~d}(J=12.2 \mathrm{~Hz})$ & Me-20, H-19a & $4.29 \mathrm{~d}(J=12.2 \mathrm{~Hz})$ & $\mathrm{C}-5, \mathrm{C}-4, \mathrm{C}-6$ \\
\hline $\mathrm{Me}-20$ & $0.79 \mathrm{~s}$ & Me-17, H-1 $\alpha, \mathrm{H}-12, \mathrm{H}-19 \mathrm{~b}, \mathrm{H}-19 \mathrm{a}$ & $0.89 \mathrm{~s}$ & $\mathrm{C}-11, \mathrm{C}-9, \mathrm{C}-10, \mathrm{C}-8$ \\
\hline 8-OAc & & & $2.21 \mathrm{~s}$ & $167.85(\mathrm{C}=\mathrm{O})$ \\
\hline 19-OAc & $2.11 \mathrm{~s}$ & & $2.14 \mathrm{~s}$ & $170.63(\mathrm{C}=\mathrm{O})$ \\
\hline 6-OAc & & & $2.10 \mathrm{~s}$ & $169.33(\mathrm{C}=\mathrm{O})$ \\
\hline 3-OAc & $2.03 \mathrm{~s}$ & & $2.02 \mathrm{~s}$ & $169.68(\mathrm{C}=\mathrm{O})$ \\
\hline $\mathrm{OH}^{c}$ & $5.59 \mathrm{~s}$ & & $4.24 \mathrm{~s}$ & $\mathrm{C}-1, \mathrm{C}-9, \mathrm{C}-10$ \\
\hline $\mathrm{OH}^{c)}$ & $4.75 \mathrm{~s}$ & & & \\
\hline $\mathrm{OH}^{c}$ & $3.73 \mathrm{~s}$ & & & \\
\hline
\end{tabular}

a) This is the endo hydrogen with respect to ring B. b) This is the exo hydrogen with respect to ring B. c) Disappeared after addition of $\mathrm{D}_{2} \mathrm{O}$. o.s. overlapped signal. 
armigera) was used to evaluate the activity of the compounds against the final stadium larvae of Lepidoptera. ${ }^{28)}$ The compounds isolated from Teucrium orientale differed in their potency on the feeding behaviour of the larvae.

Table 4 shows that the neo-clerodane teucrolivin A (1) was the most potent antifeedant against all three species of Lepidoptera. It was the only compound tested with the epoxy as well as the C-6 and C-19 acetate moieties. The activity declined in teucrolivin B (2) and teucrolivin C (3), compounds that lack the acetate moiety at C-6. A similar trend in decreasing activity from compound $\mathbf{1}$ to compound $\mathbf{3}$ was observed for all three species of insects. These data support earlier suggestions that the presence of the epoxy as well as the acetate contributes to the potency of the compounds. However, we cannot attribute the antifeedant activity of the neo-clerodanes to the presence or absence of this one specific functional group on the molecule, ${ }^{9}$ ) other functional groups are important to the antifeedant and astringent properties of these molecules.

Table 3. ${ }^{13} \mathrm{C}-\mathrm{NMR}$ Spectral Data of Compounds 4, 5, 6 and $7(150.9 \mathrm{MHz}$, $\mathrm{CDCl}_{3}$ )

\begin{tabular}{|c|c|c|c|c|}
\hline $\mathrm{C}$ & 4 & 5 & 6 & 7 \\
\hline 1 & $29.67 \mathrm{t}$ & $28.20 \mathrm{t}$ & $27.45 \mathrm{t}$ & $28.23 \mathrm{t}$ \\
\hline 2 & $25.23 \mathrm{t}$ & $36.43 \mathrm{t}$ & $25.09 \mathrm{t}$ & $24.99 \mathrm{t}$ \\
\hline 3 & $203.74 \mathrm{~s}$ & $204.26 \mathrm{~s}$ & $66.30 \mathrm{~d}$ & $66.41 \mathrm{~d}$ \\
\hline 4 & $64.69 \mathrm{~s}$ & $64.39 \mathrm{~s}$ & $61.29 \mathrm{~s}$ & $62.94 \mathrm{~s}$ \\
\hline 5 & $48.48 \mathrm{~s}$ & $48.62 \mathrm{~s}^{a)}$ & $55.53 \mathrm{~s}$ & $55.86 \mathrm{~s}$ \\
\hline 6 & $65.20 \mathrm{~d}$ & $68.86 \mathrm{~d}$ & $71.54 \mathrm{~d}$ & $70.10 \mathrm{~d}$ \\
\hline 7 & $25.76 \mathrm{t}$ & $33.62 \mathrm{t}$ & $208.56 \mathrm{~s}$ & $199.25 \mathrm{~s}$ \\
\hline 8 & $86.07 \mathrm{~s}$ & $33.85 \mathrm{~d}$ & $84.33 \mathrm{~s}$ & $92.12 \mathrm{~s}$ \\
\hline 9 & $52.25 \mathrm{~s}$ & $49.29 \mathrm{~s}^{a)}$ & $49.58 \mathrm{~s}$ & $50.94 \mathrm{~s}$ \\
\hline 10 & $82.96 \mathrm{~s}$ & $89.81 \mathrm{~s}$ & $82.27 \mathrm{~s}$ & $82.59 \mathrm{~s}$ \\
\hline 11 & $46.21 \mathrm{t}$ & $50.58 \mathrm{t}$ & $31.31 \mathrm{t}$ & $32.38 \mathrm{t}$ \\
\hline 12 & $103.02 \mathrm{~s}$ & $100.82 \mathrm{~s}$ & $22.31 \mathrm{t}$ & $22.39 \mathrm{t}$ \\
\hline 13 & $121.38 \mathrm{~s}$ & $132.00 \mathrm{~s}$ & $124.98 \mathrm{~s}$ & $124.36 \mathrm{~s}$ \\
\hline 14 & $108.65 \mathrm{~d}$ & $108.14 \mathrm{~d}$ & $110.74 \mathrm{~d}$ & $110.56 \mathrm{~d}$ \\
\hline 15 & $143.27 \mathrm{~d}$ & $143.93 \mathrm{~d}$ & $142.90 \mathrm{~d}$ & $143.17 \mathrm{~d}$ \\
\hline 16 & $140.33 \mathrm{~d}$ & $138.26 \mathrm{~d}$ & $138.56 \mathrm{~d}$ & $138.67 \mathrm{~d}$ \\
\hline 17 & $24.89 \mathrm{q}$ & $16.04 \mathrm{q}$ & $17.04 \mathrm{q}$ & $15.55 \mathrm{q}$ \\
\hline 18 & $52.59 \mathrm{t}$ & $52.51 \mathrm{t}$ & $46.10 \mathrm{t}$ & $45.82 \mathrm{t}$ \\
\hline 19 & $61.03 \mathrm{t}$ & $60.89 \mathrm{t}$ & $63.26 \mathrm{t}$ & $62.52 \mathrm{t}$ \\
\hline 20 & $12.86 \mathrm{q}$ & $15.28 \mathrm{q}$ & $19.00 \mathrm{q}$ & $16.36 \mathrm{q}$ \\
\hline \multirow[t]{8}{*}{ Ac } & $169.96 \mathrm{~s}$ & $169.90 \mathrm{~s}$ & $171.15 \mathrm{~s}$ & $170.63 \mathrm{~s}$ \\
\hline & & & $169.74 \mathrm{~s}$ & $169.68 \mathrm{~s}$ \\
\hline & & & & $169.33 \mathrm{~s}$ \\
\hline & & & & 167.85 \\
\hline & $20.58 \mathrm{q}$ & $20.48 \mathrm{q}$ & $20.85 \mathrm{q}$ & $21.45 \mathrm{q}$ \\
\hline & & & $20.95 \mathrm{q}$ & $20.93 \mathrm{q}$ \\
\hline & & & & $20.93 \mathrm{q}$ \\
\hline & & & & $20.69 \mathrm{q}$ \\
\hline
\end{tabular}

a) These values may be reversed. Multiplicities were established by DEPT pulse sequence.

\section{Experimental}

General Experimental Procedures IR spectra were determined with a Perkin Elmer 257 instrument. Optical rotation were recorded on Jasco P-1010 polarimeter. ${ }^{1} \mathrm{H}$ - and ${ }^{13} \mathrm{C}-\mathrm{NMR}$ spectra were obtained on Bruker AMX-600 operating at 600.13 and $150.9 \mathrm{MHz}$ for proton and carbon respectively. DEPT experiments were acquired on a Bruker AMX-300 spectrometer. Measurements were made on solution in $\mathrm{CDCl}_{3}$, chemical shifts were referred to TMS set at $0 \mathrm{ppm}$, and coupling constants are given in $\mathrm{Hz}$. Heteronuclear two-dimensional ${ }^{1} \mathrm{H}-{ }^{13} \mathrm{C}$ correlations, one-bond $\mathrm{HMQC}$ (heteronuclear multiple quantum correlation) and long-range $\mathrm{HMBC}$ (heteronuclear multiple bond correlation), were carried out in the ${ }^{1} \mathrm{H}-\mathrm{de}-$ tected mode with broad-band decoupling in the ${ }^{13} \mathrm{C}$ domain. ROESY experiments were obtained using as spin-lock a continuous low power transmitter pulse and mixing time of 0.2 and $0.4 \mathrm{~s}$, using standard BRUKER pulse sequence. MS were recorded on a Finnigan TSQ70 instrument $(70 \mathrm{eV}$, direct inlet). Elemental analysis was carried out with a Perkin-Elmer 240 apparatus. Flash chromatography was performed by using silica gel (Merck, $0.040-0.063$ mesh).

Plant Material Aerial parts of T. orientale L. were collected in June 2001, at Chagoura, Cèdres de Bècharrè, Lebanon, at $2000 \mathrm{msl}$ and voucher specimens are deposited in the Herbarium, Botanischer Garten und Botanisches Museum, Freie Universitat, Berlin (leg. and det. N. Arnold s.n., confirm. Th. Raus) and also in the Herbarium, Botanical Garden, Palermo, Italy under the number PAL 2001-1456.

Extraction and Isolation Dried and finely powdered $T$. orientale parts $(1153 \mathrm{~g})$ were extracted with $\mathrm{Me}_{2} \mathrm{CO}(3 \times 51)$ at room temp. for 1 week. The residue $(90 \mathrm{~g})$ obtained by removal of the solvent at reduced pressure, was chromatographed on a silica gel (Merck, Art. 7754, deactivated with $15 \%$ $\mathrm{H}_{2} \mathrm{O}, 500 \mathrm{~g}$ ) column, packed in petroleum ether, using a petroleum ether-EtOAc gradient solvent system $(0 \rightarrow 80 \%$ EtOAc in petroleum ether, total 61) followed by EtOAc (11) and a mixture of EtOAc and $\mathrm{MeOH}(9: 1$, 11). The fraction eluted with petroleum ether-EtOAc $80 \%$ was purified by column chromatography $\left(\mathrm{CH}_{2} \mathrm{Cl}_{2}-\mathrm{MeOH} 2 \%\right)$ to afford in order of increasing polarity teucrolivin A $(\mathbf{1}, 50 \mathrm{mg}), 6$-deacetyl-teucrolivin $\mathrm{A}(\mathbf{5}, 7 \mathrm{mg})$, teucrolivin $\mathrm{H}(\mathbf{4}, 20 \mathrm{mg})$, teucrolivin $\mathrm{B}(\mathbf{2}, 360 \mathrm{mg})$ and $8 \beta$-hydroxy-teucrolivin $\mathrm{B}(\mathbf{6}, 10 \mathrm{mg})$. The fraction eluted with petroleum EtOAc was purified by column chromatography $\left(\mathrm{CH}_{2} \mathrm{Cl}_{2}-\mathrm{MeOH} 4 \%\right)$ to afford clean teucrolivin C (3, $83 \mathrm{mg})$.

6-Deacetyl-teucrolivin A (5): Amorphous solid. $[\alpha]_{\mathrm{D}}^{25}+39.60^{\circ}(c=1.0$, $\mathrm{CHCl}_{3}$ ). IR (film) $\mathrm{cm}^{-1}: 3490,3450,3040,2950,2950,2874,1745,1725$, 1505, 1460, 1383, 1273, 1229, 1190, 1159, 1136, 1037, 974, 945, 874. ${ }^{1} \mathrm{H}-\mathrm{NMR}$ spectral data: see Table $1 .{ }^{13} \mathrm{C}$-NMR spectral data: see Table 3 . EI-MS m/z: $420\left[\mathrm{M}^{+}\right.$(1), 403 (10), 329 (8), 311 (9), 279 (52), 219 (17), 201 (199), 174 (18), 167 (50), 149 (100). Anal. Calcd for $\mathrm{C}_{22} \mathrm{H}_{28} \mathrm{O}_{8}: \mathrm{C}, 62.84 ; \mathrm{H}$, 6.71. Found: C, $62.66 ; \mathrm{H}, 6.61$

Teucrolivin A (1) from 6-Deacetyl-teucrolivin A (5): Acetic anhydridepyridine $(2 \mathrm{ml}, 2: 1)$ treatment of $5(7 \mathrm{mg})$ at room temperature for $24 \mathrm{~h}$ gave after the usual work up $6 \mathrm{mg}$ of teucrolivin A (1) identical in all respects (TLC, ${ }^{1} \mathrm{H}-$ and ${ }^{13} \mathrm{C}-\mathrm{NMR}, \mathrm{IR}$ and $[\alpha]_{\mathrm{D}}$ ) with the previously described compound.

$8 \beta$-Hydroxy-teucrolivin B (6): Amorphous solid. $[\alpha]_{\mathrm{D}}^{25}+7.47^{\circ}(c=1.52$, $\mathrm{CHCl}_{3}$ ). IR (nujol) $\mathrm{cm}^{-1}: 3385,1740,1720,1460,1377,1248,1159,1041$, 1024, 947, 893, 874. ${ }^{1} \mathrm{H}-\mathrm{NMR}$ spectral data: see Table $2 .{ }^{13} \mathrm{C}$-NMR spectral data: see Table 3. EI-MS $m / z: 480[\mathrm{M}]^{+}$(4), 462 (59), 447 (16), 402 (20), 368 (46), 311 (46), 266 (62), 218 (100), 189 (60), 161 (50), 148 (42). Anal. Calcd for $\mathrm{C}_{24} \mathrm{H}_{32} \mathrm{O}_{10}$ : C, 59.99; $\mathrm{H}, 6.71$. Found: C, 59.88; H, 6.59.

Acetylation of $8 \beta$-Hydroxy-teucrolivin B (6): Acetic anhydride-pyridine $(2 \mathrm{ml}, 2: 1)$ treatment of $6(10 \mathrm{mg})$ at room temperature for $24 \mathrm{~h}$ gave after the usual work up $10 \mathrm{mg}$ of the tetraacetyl (7) as an amorphous solid; $[\alpha]_{\mathrm{D}}^{25}$ $+3.63^{\circ}\left(c=1.10, \mathrm{CHCl}_{3}\right)$. IR (film) $\mathrm{cm}^{-1}: 3562,3020,2950,2925,2854$,

Table 4. Effect of Neo-clerodanes on the Feeding Behaviour of Final Stadium Lepidopteran Larvae

\begin{tabular}{llll}
\hline \hline & & \multicolumn{2}{c}{ Feeding index $^{a)}$ mean \pm S.E.M. ${ }^{b)}\left(\mathrm{FI}_{50}\right)^{c)}$} \\
\cline { 2 - 4 } Neo-clerodane $^{d)}$ & \multicolumn{1}{c}{$\mathbf{1}$} & $\mathbf{2}$ & $\mathbf{3}$ \\
\hline Spodoptera littoralis & $54 \pm 10.4^{*}(3 \mathrm{ppm})$ & $37 \pm 9.5^{*}(650 \mathrm{ppm})$ & $29 \pm 7.8(>1000 \mathrm{ppm})$ \\
Spodoptera frugiperda & $53 \pm 9.2^{*}(\mathrm{nc})$ & $36 \pm 11.7^{e}(\mathrm{nc})$ & $18 \pm 11.1(\mathrm{nc})$ \\
Helicoverpa armigera & $52 \pm 11.4^{*}(70 \mathrm{ppm})$ & $25 \pm 12.3^{e)}(>1000 \mathrm{ppm})$ & $22 \pm 8.3(>1000 \mathrm{ppm})$ \\
\hline
\end{tabular}

a) Feeding index $=((\mathrm{C}-\mathrm{T}) /(\mathrm{C}+\mathrm{T})) \%, \mathrm{C}=$ amount of control discs, $\mathrm{T}=$ amount of treatment discs eaten after an $18 \mathrm{~h}$ bioassay. $\quad b)$ Feeding index (mean $\pm \mathrm{S}$.E.M.) at $100 \mathrm{ppm}$. c) Estimated concentration (ppm) to give feeding index of $50 \%, \mathrm{nc}=$ not calculated. d) Figure 1 contains structures of compounds. e) Previously published in ref. 29.*=significant $p<0.05$, Wilcoxon matched pairs test, $n=20$. 
1750, 1738, 1725, 1655, 1502, 1435, 1369 1250, 1235, 1168, 1117, 1085, 1041 975, 930, 897, 874. ${ }^{1} \mathrm{H}-\mathrm{NMR}$ spectral data: see Table $2 .{ }^{13} \mathrm{C}-\mathrm{NMR}$ spectral data: see Table 3. EI-MS m/z: $564\left[\right.$ [M] $^{+}$(1), 547 (3), 504 (6), 444 (2), 385 (12), 367 (10), 308 (18), 281 (16), 265 (21), 248 (40), 218 (38), 177 (100), 121 (38), 109 (76). Anal. Calcd for $\mathrm{C}_{28} \mathrm{H}_{34} \mathrm{O}_{12}: \mathrm{C}, 59.77 ; \mathrm{H}, 6.09$. Found: C, 59.68; H, 6.12.

Antifeedant Activity Bioassay Compounds $\mathbf{1}-\mathbf{3}$ were tested in a binary glass-fibre choice test ${ }^{28)}$ for antifeedant activity. The three compounds were all tested at $100 \mathrm{ppm}$ against $18-24 \mathrm{~h}$ old final stadium larvae of the three species of Lepidoptera. Lower concentrations were also tested against larvae of S. littoralis and H. armigera. Regression analysis was used to estimate the $\mathrm{FI}_{50}$. Each concentration was tested against 5-20 larvae per species.

Acknowledgements Work in Palermo was supported by Italian Government project PRIN 2003. Insects were cultured in UK under conditions specified in a Defra license.

\section{References and}

1) Willis J. C., "A Dictionary of the Flowering Plants and Ferns," Cambridge Universiy Press, Cambridge, 1966, p. 1113.

2) Greuter W., Burdet H. M., Long G., "Med-Checklist," Vol. 3, Conservatoire et Jardin Botanique de la Ville de Genève, Genéve, 1986, pp. $366-380$.

3) Piozzi F., Heterocycles, 15, 1489-1503 (1981).

4) Piozzi F., Savona G., Rodriguez B., Heterocycles, 25, 807-841 (1987).

5) Piozzi F., Heterocycles, 37, 603-626 (1994)

6) Piozzi F., Bruno M., Rosselli S., Heterocycles, 48, 2185-2203 (1998).

7) van Beek T. A., de Groot Ae., Rec. Trav. Chim. Pays-Bas., 105, 513527 (1986).

8) Bruno M., Piozzi F., Maggio A. M., Rosselli S., Simmonds M. S. J., Servettaz O., Biochem. Syst. Ecol., 30, 595-599 (2002).

9) Gebbinck E. A. K., Jansen B. J. M., de Groot Ae., Phytochemistry, 61 , $737-770$ (2002).

10) Rasekh H. R., Khoshnood-Mansourkhani M. J., Kamalinejad M.,
Fitoterapia, 72, 937-939 (2001).

11) Gharaibeh M. N., Elayan H. H., Salhab A. S., J. Ethnopharmacol., 24 93-99 (1988).

12) Roman-Ramos R., Flores-Saenz J. L., Partida-Hernandez G., LaraLemus A., Alarcon-Aguilar F., Arch. Invest. Med., 22, 87-93 (1991).

13) Tariq M., Ageel A. M., Al-Yahya M. A., Mossa J. S., Al-Said M. S., Int. J. Tissue. React., 11, 185-188 (1989).

14) Fernandez P. B., Iglesias P. I., Villar del Frenso A. M., J. Ethnopharmacol., 55, 93-98 (1997).

15) Galati E. M., Mondello R. M., D’Aquino A., Miceli N., Sango R., Tzakou O., Monforte M. T., J. Ethnopharmacol., 72, 337-342 (2000).

16) Couladis M., Tzakou O., Veykokidou E., Harvala C., Phytother. Res., 17, 194-195 (2003).

17) Nagao Y., Ito N., Kohno T., Kuroda H., Fujita E., Chem. Pharm. Bull., 30, 727 (1982).

18) Autore G., Capasso F., de Fusco R., Fasulo M. P., Lembo M., Mascolo N., Menghini A., Pharmacol. Res. Commun., 16, 21-29 (1984).

19) Bruno M., Omar A. A., Perales A., Piozzi F., Rodriguez B., Savona G., de la Torre M. C., Phytochemistry, 30, 275-282 (1991).

20) de la Torre M. C., Bruno M., Piozzi F., Savona G., Rodriguez B., Omar A. A., Phytochemistry, 30, 1603-1606 (1991).

21) de la Torre M. C., Bruno M., Piozzi F., Savona G., Omar A. A., Perales A., Rodriguez B., Tetrahedron, 47, 3463-3470 (1991).

22) Al-Yahya M. A., Muhammad I., Mirza H. H., El-Feraly F. S., McPhail A. T., J. Nat. Prod., 56, 830-842 (1993).

23) Al-Yahya M. A., Muhammad I., Mirza H. H., El-Feraly F. S., McPhail A. T., J. Nat. Prod., 58, 633 (1995).

24) Al-Yahya M. A., El-Feraly F. S., Dunbar D. C., Muhammad I., Phytochemistry, 59, 409-414 (2002).

25) Boulos L., "Medicinal Plants of North Africa," Reference Publications, Michigan, 1983, p. 112.

26) Bax A., Morris G., J. Magn. Reson., 42, 501-505 (1981).

27) Bax A., Summers M. F., J. Am. Chem. Soc., 108, 2093-2094 (1986).

28) Simmonds M. S. J., Blaney W. M., Fellows L. E., J. Chem. Ecol., 16, 3167-3196 (1990).

29) Bruno M., Rosselli S., Pibiri I., Piozzi F., Simmonds M. S. J., Heterocycles, 53, 599-612 (2000). 